\title{
A COOK-FÉLE MEMBRÁN FELADAT MEGOLDÁSA p-VERZIÓS VÉGESELEM-MODELLEKKEL
}

\author{
Szőcs Tamás \\ BSc hallgató, Miskolci Egyetem, Müszaki Mechanikai Intézet \\ 3515 Miskolc, Miskolc-Egyetemváros, e-mail: szocstomcsi@gmail.com \\ Bertóti Edgár \\ egyetemi tanár, Miskolci Egyetem, Müszaki Mechanikai Intézet \\ 3515 Miskolc, Miskolc-Egyetemváros, e-mail: mechber@uni-miskolc.hu
}

\begin{abstract}
Absztrakt
Ez a cikk egy szakirodalomból jól ismert sík-rugalmasságtani peremérték-feladat, a Cook-féle membrán probléma numerikus megoldásán keresztül veti össze az elsörendü feszültségfüggvényeken és forgásokon alapuló, p-verziós dual-mixed végeselem-modellt és a klasszikus, elmozdulásmezön alapuló p-verziós végeselem-modellt.
\end{abstract}

Kulcsszavak: p-verziós végeselemek, dual-mixed modell, Cook-féle membrán feladat

\section{Abstract}

This paper compares the performance of the classical, displacement-based p-version finite element model and a dual-mixed finite element model, based on the approximation of first-order stress functions and rotations, through the numerical solution of Cook's membrane problem, a well-known plane elasticity benchmark problem.

Keywords: p-version finite elements, dual-mixed model, Cook's membrane problem

\section{Bevezetés}

A rugalmasságtani problémák megoldására kifejlesztett klasszikus, elmozdulásmezőn alapuló, $h$-verziós - alacsonyrendủ approximációval és elemsürítéssel dolgozó - végeselem-modellek numerikus konvergencia problémái többféleképpen is elkerülhetők. Az egyik lehetőség - az elmozdulásmező alapváltozóként való megtartásával - a $p$-verziós, magasabb rendủ approximációval dolgozó elemek alkalmazása [1]. Egy másik lehetőség olyan, egy- vagy többmezős variációs elven alapuló, ún. mixed végeselemmodellek alkalmazása, amelyeknél a feszültségi változók közvetlen approximációja is biztosítva van [2]. Utóbbi modellek és elemek mind $h$-, mind $p$-verziós változatukban hatékonyaknak bizonyultak, hátrányuk az, hogy egyrészt bonyolultabb felépítésüek, másrészt az approximációs tereknek egy stabilitási kritériumot is ki kell elégíteniük [2][3].

A feszültségmező közelítésén alapuló végeselem-modellek a feszültségi tenzor szimmetriájának biztosítási módjától függően többféleképpen is felépíthetők. Egyensúlyi, a priori szimmetrikus feszültségmezőn alapuló h-verziós végeselem-modelleket kizárólag síkbeli feladatok numerikus megoldására fejlesztettek ki, lásd pl. [4][5][6]. Ezek az elemek azonban nem kaptak jelentős szerepet az alkalmazásokban, aminek elsődleges oka az egyensúlyt biztosító másodrendü feszültségfüggvényekre vonatkozó $C^{1}$ - 
folytonossági approximációs követelményben és az ebből fakadó bonyolult, nehezen kezelhető elemekben, valamint a feszültségi peremfeltételek figyelembevételénél megjelenő numerikus nehézségekben keresendők.

Az említett problémák a feszültségi tenzor szimmetriájának variációs úton történő biztosításával elkerülhetők. Ebben az esetben a transzlációs egyensúly kielégítése csak elsőrendủ feszültségfüggvényeket kíván, amelyek $C^{0}$-folytonos approximációja egyben az elemek közötti normál irányú feszültségvektorok folytonosságát is biztosítani fogja, a feszültségi tenzor szimmetriáját kifejező forgási egyensúlyi egyenlet a forgásmező Lagrange-féle multiplikátorként való alkalmazásával biztosítható. A modellezés alapját a Fraeijs de Veubeke-féle kétmezős variációs elv jelenti [7]. Ilyen típusú $h$-verziós, ún. dual-mixed végeselem-modelleket fejlesztett ki, többek között, lineáris sík-rugalmasságtani feladatokra [8][9][5], nemlineáris síkbeli feladatokra [10][11][12] és rugalmas-képlékeny feladatokra [13][14]. Síkrugalmasságtani problémák és lemezfeladatok megoldására alkalmas $p$ - és $h p$-verziós végeselem-modellek mutat be [15] és [16].

Ez a cikk a $[15,16]$ munkákban ismertetett, feszültségfüggvényeken és forgásokon alapuló, $p$-verziós dual-mixed végeselem-modellt veti össze az elmozdulásmezőn alapuló $p$-verziós végeselem-modellel egy szakirodalomból jól ismert sík-rugalmasságtani peremérték-feladat, a Cook-féle membrán probléma numerikus megoldásán keresztül. A 2. fejezet ismerteti a Fraeijs de Veubeke-féle variációs elvet, majd származtatja annak sík-rugalmasságtani feladatokra érvényes alakját. A 3. fejezet a számítások során alkalmazott $p$-verziós végeselem-modellt mutatja be, ismertetve a feszültségfüggvények és a forgásmező közelítésére alkalmazott optimális és stabil approximációs teret. Végül a 4. fejezetben a szakirodalomban gyakran tesztelt Cook-féle membrán feladat numerikus megoldásán keresztül összevetésre kerül a feszültségmezőn és forgásmezőn alapuló $p$-verziós végeselem-modell a klasszikus, elmozdulásmezőn alapuló $p$-verziós modellel.

\section{Variációs elv feszültségmezővel és forgásmezővel}

A feszültségmezőn és forgásmezőn alapuló végeselem-módszer elméleti hátterét a Fraeijs de Veubekeféle variációs elv [7] jelenti, amelynek funkcionálja a lineáris rugalmasságtan keretei között az

$$
\mathcal{F} \boldsymbol{\sigma}, \boldsymbol{\phi}=\int_{V} W_{c}(\boldsymbol{\sigma})+\boldsymbol{\sigma}: \boldsymbol{\phi} \mathrm{d} V-\int_{S u} \tilde{\boldsymbol{u}} \cdot \boldsymbol{\sigma} \cdot \boldsymbol{n} \mathrm{d} S
$$

alakban írható, ahol $V$ a test térfogati tartománya, $\sigma$ a feszültségi tenzor, $\phi$ a szögelfordulás-tenzor, $\tilde{\boldsymbol{u}}$ az elöírt elmozdulásmező a test $\boldsymbol{n}$ normálisú $S_{u}$ peremfelület-részén, továbbá

$$
W_{c}(\boldsymbol{\sigma})=\frac{1}{2} \boldsymbol{\sigma}: \mathbb{C}^{-1}: \boldsymbol{\sigma}
$$

a test térfogategységében ébredő kiegészítő alakváltozási energia, amelyben $\mathbb{C}^{-1}$ az anyagállandók negyedrendủ rugalmassági tenzora. Az (1) funkcionálhoz tartozó kiegészítő feltételek a

$$
\boldsymbol{\sigma} \cdot \nabla+\rho \boldsymbol{b}=\mathbf{0}, \quad x \in V
$$

transzlációs egyensúlyi egyenlet, ahol $\rho$ a test sürüsége, $\boldsymbol{b}$ pedig a térfogati erőrendszer sürüségvektora, továbbá a

$$
\boldsymbol{\sigma} \cdot \boldsymbol{n}=\tilde{\boldsymbol{p}}, \quad x \in S_{p}
$$

feszültségi peremfeltétel, ahol $\tilde{\boldsymbol{p}}$ az $S_{p}$ peremfelület-részen elöírt terhelés intenzitása, valamint a $\boldsymbol{\phi}$ szögelfordulás-tenzor

$$
\phi+\phi^{T}=0
$$


egyenlettel kifejezett aszimmetriája, ahol a jobb felső indexben álló $T$ a transzponálásra utal. Az $S=S_{u} \cup S_{p} \quad\left(S_{u} \cap S_{p}=\varnothing\right)$ peremfelülettel lezárt $V$ tartomány egy tetszőleges pontjának helyvektorát egy alkalmasan megválasztott vonatkoztatási rendszerben $\boldsymbol{x}$ jelöli.

Sík-rugalmasságtani feladatok. Sík-rugalmasságtani peremérték-feladatok esetén - xyz Descartes-i derékszögü koordináta-rendszert alkalmazva - feltételezzük, hogy a test $V$ tartományának kiválasztott és vizsgált, $\Omega$-val jelölt síkmetszete az xy síkban helyezkedik el. Az $\Omega$ tartomány peremgörbéjét $\Gamma$ jelöli. Lineárisan rugalmas, izotrop anyagmodell feltételezésével az (1) funkcionál az

$$
\begin{aligned}
\mathcal{F} \boldsymbol{\sigma}, \boldsymbol{\phi}= & \frac{1}{2} \int_{\Omega} \frac{1}{2 \mu}\left[\frac{1}{1+\nu_{1}}\left(\sigma_{x}^{2}+\sigma_{y}^{2}-2 \nu_{1} \sigma_{x} \sigma_{y}\right)+\frac{1}{2}\left(\tau_{x y}+\tau_{y x}\right)^{2}\right] \mathrm{d} \Omega \\
& \quad+\int_{\Omega} \varphi\left(\tau_{y x}-\tau_{x y}\right) \mathrm{d} \Omega \\
& -\int_{\Gamma_{u}}\left[\tilde{u}_{x}\left(\sigma_{x} n_{x}+\tau_{x y} n_{y}\right)+\tilde{u}_{y}\left(\tau_{y x} n_{x}+\sigma_{y} n_{y}\right)\right] \mathrm{d} s
\end{aligned}
$$

alakban írható, amelyben $\varphi \equiv \varphi_{z}$ a $\phi$ forgástenzor egyetlen koordinátája, $\mu$ a nyírási rugalmassági modulus, továbbá $\nu_{1}$ az általánosított Poisson-tényező, amely sík-feszültségi feladatoknál a $\nu_{1}=\nu$, sík-alakváltozási feladatoknál pedig a $\nu_{1}=\nu /(1-\nu)$ módon számítható az anyag $\nu$ Poisson-tényezőjéből. A $\Gamma=\Gamma_{u} \cup \Gamma_{p}\left(\Gamma_{u} \cap \Gamma_{p}=\varnothing\right)$ peremgörbén mért ívkoordinátát $s$ jelöli, $\boldsymbol{n}=n_{x} \boldsymbol{e}_{x}+n_{y} \boldsymbol{e}_{y}$ pedig a peremgörbe tartományból kifelé mutató normálisa az $e_{x}, e_{y}$ bázisban felírva. Az (1), illetve a (6) funkcionálhoz tartozó kiegészítő feltételek közül a (3) egyensúlyi egyenlet a

$$
\begin{aligned}
& \sigma_{x, x}+\sigma_{x y, y}+\rho b_{x}=0, \\
& \sigma_{y x, y}+\sigma_{y, y}+\rho b_{y}=0,
\end{aligned} \quad x, y \in \Omega
$$

alakban érvényes, ahol az indexben álló vessző utáni betủ parciális deriválást jelöl az $x$ vagy az $y$ koordináta szerint, a (4) feszültségi peremfeltétel az

$$
\begin{aligned}
& n_{x} \sigma_{x}+n_{y} \sigma_{x y}=\tilde{p}_{x}, \\
& n_{x} \sigma_{y x}+n_{y} \sigma_{y}=\tilde{p}_{y}, \quad x, y \in \Gamma_{p}
\end{aligned}
$$

alakot veszi fel, az (5) aszimmetria-feltétel pedig már figyelembe lett véve a (6) funkcionálban azáltal, hogy síkbeli feladatok esetén a $\phi$ tenzornak egyetlen $\varphi \equiv \varphi_{z}$ koordinátája különbözik zérustól, amely nem más, mint az $x y$ síkra merőleges $\varphi \equiv \varphi_{z} \boldsymbol{e}_{z}$ forgásvektor koordinátája.

A (7) szerinti transzlációs egyensúlyi egyenleteket kielégítő, önegyensúlyi feszültségmező egy tetszőleges, differenciálható

$$
\boldsymbol{\psi}(x, y)=\psi_{x} e_{x}+\psi_{y} e_{y}
$$

elsőrendü feszültségfüggvény-vektor bevezetésével származtatható a

$$
\begin{aligned}
& \sigma_{x}=\psi_{x, y}+B, \\
& \sigma_{y}=-\psi_{y, x}+B, \\
& \tau_{x, y}=-\psi_{x, x}, \\
& \tau_{y, x}=\psi_{y, y},
\end{aligned}
$$

összefüggéseknek megfelelően, ahol $B$ a térfogati erőrendszer skalár-potenciálja:

$$
\rho b_{x}=-B,_{x}, \quad \rho b_{y}=-B,_{y}, \quad x, y \in \Omega
$$


A (8) feszültségi peremfeltétel elsőrendủ feszültségfüggvényekkel kifejezett alakja

$$
\boldsymbol{\sigma} \cdot \boldsymbol{n}=\frac{\mathrm{d} \boldsymbol{\psi}}{\mathrm{d} s}-B \boldsymbol{n}=\tilde{\boldsymbol{p}}, \quad x, y \in \Gamma_{p} .
$$

A (6) funkcionálban megjelenő nyírófeszültség-különbség a $\psi$ feszültségfüggvénnyel a

$$
\tau_{y x}-\tau_{x y}=\operatorname{div} \boldsymbol{\psi}
$$

alakban írható, amiből az is következik, hogy szimmetrikus feszültségek esetében $\boldsymbol{\psi}$ divergenciája zérus kell legyen.

Behelyettesítve a (10)-(13) feszültségeket a (6) funkcionálba, majd képezve annak irány menti deriváltjait a $\psi$ és $\varphi$ helyeken a tetszöleges $\delta \psi$ és $\delta \varphi$ irányokban, a

$$
\begin{aligned}
D_{\delta \psi} \mathcal{F} \psi, \varphi=\frac{1}{2} \int_{\Omega} & \frac{1}{2 \mu\left(1+\nu_{1}\right)}\left[\psi_{x, y} \delta \psi_{x, y}+\psi_{y, x} \delta \psi_{y, x}+\nu_{1}\left(\psi_{x, y} \delta \psi_{y, x}+\psi_{y, x} \delta \psi_{x, y}\right)\right. \\
& \left.+\frac{1}{2}\left(\psi_{y, y}-\psi_{x, x}\right)\left(\delta \psi_{y, y}-\delta \psi_{x, x}\right)\right] \mathrm{d} \Omega+\int_{\Omega} \varphi\left(\delta \psi_{x, x}+\delta \psi_{y, y}\right) \mathrm{d} \Omega \\
& -\int_{\Gamma_{u}}\left[\tilde{u}_{x} \frac{\mathrm{d}\left(\delta \psi_{x}\right)}{\mathrm{d} s}+\tilde{u}_{y} \frac{\mathrm{d}\left(\delta \psi_{y}\right)}{\mathrm{d} s}\right] \mathrm{d} s \\
D_{\delta \varphi} \mathcal{F} \boldsymbol{\psi}, \varphi= & \int_{\Omega} \delta \varphi\left(\psi_{x, x}+\psi_{y, y}\right) \mathrm{d} \Omega
\end{aligned}
$$

kifejezéseket kapjuk. A sík-rugalmasságtani peremérték-feladat ekkor a következő módon fogalmazható meg: keresett $\boldsymbol{\psi} \in \mathbb{V}$ és $\varphi \in \mathbb{W}$ a

$$
\begin{gathered}
\mathbb{V}:=\left\{\psi \mid \psi_{x}, \psi_{y} \in \mathbb{H}^{1}(\Omega), \frac{\mathrm{d} \psi}{\mathrm{d} s}=\tilde{\boldsymbol{p}}-B \boldsymbol{n} \quad x, y \in \Gamma_{p}\right\}, \\
\mathbb{W}:=\mathbb{L}^{2}(\Omega)
\end{gathered}
$$

függvényterekben - ahol $\mathbb{H}^{1}(\Omega)$ az első deriváltjaival együtt négyzetesen integrálható függvényekből, $\mathbb{L}^{2}(\Omega)$ pedig négyzetesen integrálható függvényekből álló teret jelöl az $\Omega$ tartományon - olyan módon, hogy a

$$
\begin{aligned}
& D_{\delta \psi} \mathcal{F} \boldsymbol{\psi}, \varphi=0, \\
& D_{\delta \varphi} \mathcal{F} \boldsymbol{\psi}, \varphi=0
\end{aligned}
$$

egyenlöségek minden $\delta \boldsymbol{\psi} \in \mathbb{V}_{0}$ és $\delta \varphi \times \mathbb{W}$ esetén fennálljanak, ahol $\mathbb{V}_{0}$ a $\mathbb{V}$ tér részhalmaza $\tilde{\boldsymbol{p}}=\mathbf{0}$ homogén feszültségi peremfeltételekkel a $\Gamma_{p}$ peremgörbén.

A feszültségmezőn és forgásmezőn alapuló végeselem-modellek egyik nagy előnye az elmozdulásmezőn alapuló modellekkel és elemekkel szemben az, hogy az (1), illetve a (6) funkcionálban nem jelenik meg az $1 /(1-2 \nu)$ tag. Ez azt jelenti, hogy összenyomhatatlan $(\nu \longrightarrow 0,5)$ anyagok esetén a dualmixed elemek alkalmazásával elkerülhető a szakirodalomban incompressibility-locking néven ismert numerikus konvergencia probléma. 


\section{A p-verziós dual-mixed végeselem-modell}

A többmezős variációs elveken alapuló végeselem-modellek felépítésének egyik kulcslépése a numerikusan stabil approximációs terek megválasztása. A (6) funkcionálon alapuló, feszültségfüggvény-mezőre és forgásmezőre épülő elem-modellek approximációs tereinek megválasztása a [17]-ben kimutatott azon analógia alapján történhet, miszerint a (6)-ra épülő variációs formalizmus analógiát mutat a folyadékok Stokes-féle áramlásának sebességmezőn és nyomáson alapuló variációs megfogalmazásával. Ez az analógia lehetővé teszi a [18] által kidolgozott stabil approximációs terek alkalmazását. A következőkben a négyszögelemekre [18]-ban kidolgozott hat stabil függvénytér közül egy numerikus szempontból optimális teret mutatunk be.

A $\boldsymbol{\psi}$ feszültségfüggvény-vektor és a $\varphi$ szögelfordulás, mint független mezök közelítése során feltételezzük, hogy a konvex négyszögekre bontott $\Omega$ tartomány $x, y$ koordinátákkal parametrizált négyszögelemei és a mesterelem $\xi, \eta$ koordinátákkal parametrizált négyzete között egy-egy sima, a geometriai viszonyok által meghatározott és ismertnek tekintett leképező függvény létesít kapcsolatot. Az

$$
\hat{e}=(\xi, \eta):-1 \leq \xi \leq 1,-1 \leq \eta \leq 1
$$

módon jelölt mesterelemen a feszültségfüggvényeket és a forgásmezőt polinomterekkel közelítjük, amelyek fokszámára a továbbiakban a $p$ paraméter utal ( $p>0$ egész szám).

Jelölje $P_{p}(\xi, \eta)$ azokat a polinomokat, amelyek maximális fokszáma $p$, és jelölje $Q_{p}(\xi, \eta)$ azokat a polinomokat, amelyek fokszáma mindkét változóra nézve $p$. Jelölje továbbá a $\psi_{x}$ és a $\psi_{y}$ feszültségfüggvények approximációs terét $\mathbb{V}_{p}(\xi, \eta)$, a $\varphi$ szögelfordulás approximációs terét pedig $\mathbb{W}_{p}(\xi, \eta)$. Ekkor a mesterelemen $p \geq 2$ esetén a következö stabil approximációs tereket értelmezzük a feszültségfüggvényekre és a szögelfordulásra [18]:

$$
\text { DMX: } \quad \mathbb{V}_{p}(\xi, \eta)=Q_{p} \cap P_{p+2}, \quad \mathbb{W}_{p}(\xi, \eta)=P_{p-1} .
$$

A DMX jelölés a dual-mixed elemre utal, a továbbiakban ezen a néven hivatkozunk az elemre. A $\mathbb{V}_{p}(\xi, \eta)$ és a $\mathbb{W}_{p}(\xi, \eta)$ approximációs tereket $p=4$ esetén - Pascal-féle háromszöget alkalmazva az 1. ábra szemlélteti. A DMX elem szabadsági fokok szempontjából egy optimális approximációs térrel rendelkezik a $\boldsymbol{\psi}$ feszültségfüggvényre és a $\varphi$ forgásmezőre nézve [18].

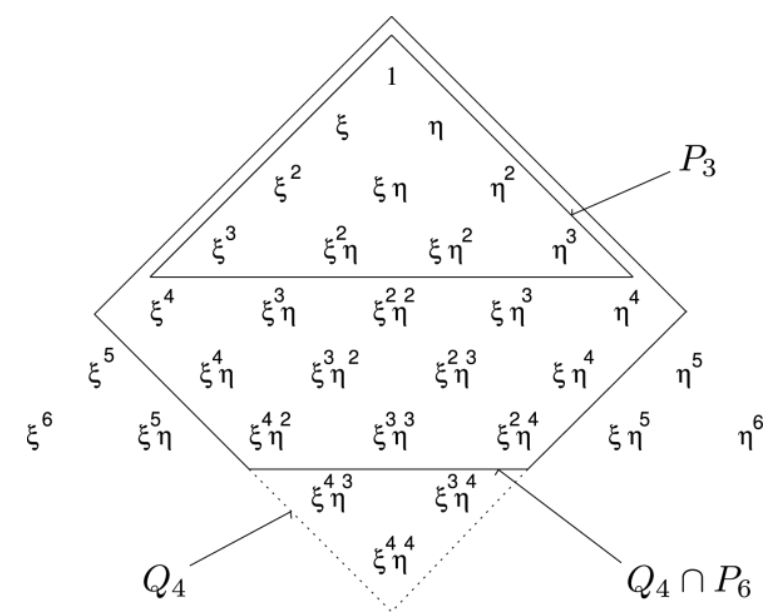

1. ábra. $A$ DMX elem (24) szerinti approximációs tere $p=4$ esetén 


\section{A Cook-féle probléma}

Ebben a részben az előző fejezetben ismertetett $p$-verziós végeselem-modellel, illetve az arra épülő végeselem-programmal számított numerikus eredményeket mutatunk be a Cook [19] által javasolt, jellegzetesen hajlítás-domináns sík-rugalmasságtani feladat estében. A probléma egzakt megoldása a lineáris rugalmasságtan keretei között sem ismert, mégis gyakori tesztfeladata a különböző végeselem-típusoknak, lásd pl. [20][21][23][24]. Meg kell azonban jegyezni, hogy a feszültségmezőre vonatkozó eredmények és összevetések ezen az egyszerü feladat esetében is csak elvétve találhatók a szakirodalomban.

A Cook-féle probléma vázlata a 2.a) ábrán látható. A trapéz alakú, $E F$ oldala mentén mereven befogott, $z$ irányban egységnyi vastagságú panelt az $A B$ oldala mentén másodfokú függvény szerint megoszló, $y$ irányú nyíróerő terhel, amelynek nagysága $1 \mathrm{kN}$. A parabola eloszlású terhelésből következően a maximális nyírófeszültség az $A B$ oldalél $G$ pontjában ébred, értéke $\tau_{y x}(G)=93,75 \mathrm{MPa}$. A numerikus megoldást sík-feszültségi állapot feltételezésével, a rugalmassági modulus $E=1 \mathrm{MPa}$ és a Poissontényező $\nu=1 / 3$ értékei esetén vizsgáljuk, alkalmazva a szakirodalomban közölt paramétereket. Megjegyzést érdemel, hogy az $A B$ oldalél mentén ható koncentrált erőt a szakirodalomban többnyire konstans eloszlású megoszló terheléssel modellezik, ami az $A$ és $B$ sarokpontokban sérti a nyírófeszültségre vonatkozó szimmetria feltételt. Az így előállított és közölt, elmozdulásmezőre vonatkozó megoldások kis mértékben különböznek a parabola eloszlásúként modellezett nyíróerővel kapott eredményektől.
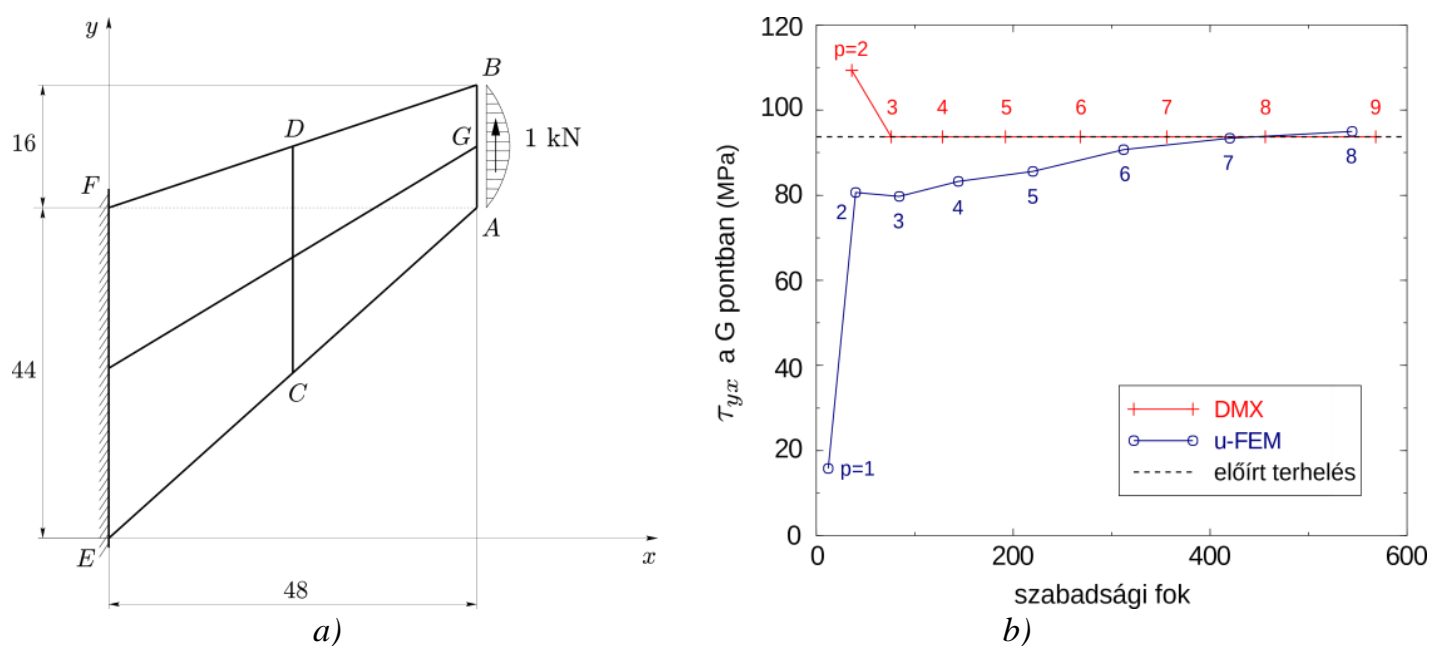

2. ábra. a) Cook-féle probléma - geometria és terhelés; b) $\tau_{y x}$ nyírófeszültség konvergenciája a G pontban

A vizsgálatok során a klasszikus, elmozdulásmezőre épülő $p$-verziós végeselem-modell és a DMX jelü, feszültségfüggvény-mezőre és forgásmezőre épülő végeselem-modell numerikus eredményeit hasonlítjuk össze a 2.a) ábrán látható, 4 elemet tartalmazó, durva felosztás esetén. Az $E$ és $F$ pontoknál megjelenő szingularitások miatt ez a végeselemes felosztás nem tekinthető megfelelőnek, a vizsgálatok célja viszont éppen az ilyen durva felosztásra vonatkozó eredmények összevetése, illetve a feszültségfüggvény-mezőre és forgásmezőre épülő $p$-verziós elemek hatékonyságának bemutatása. Egzakt megoldás hiányában az eredményeket egy olyan, a DMX elem alkalmazásával kapott, 256 elemből álló felosztással, $p=8$ esetén számolt referencia megoldáshoz viszonyítjuk, amelynek energia normában becsült hibája 0,01\%-nál kisebb. Az elmozdulásmezőn alapuló p-verziós elemekkel számolt megoldásra a továbbiakban az u-FEM jelölés utal. 


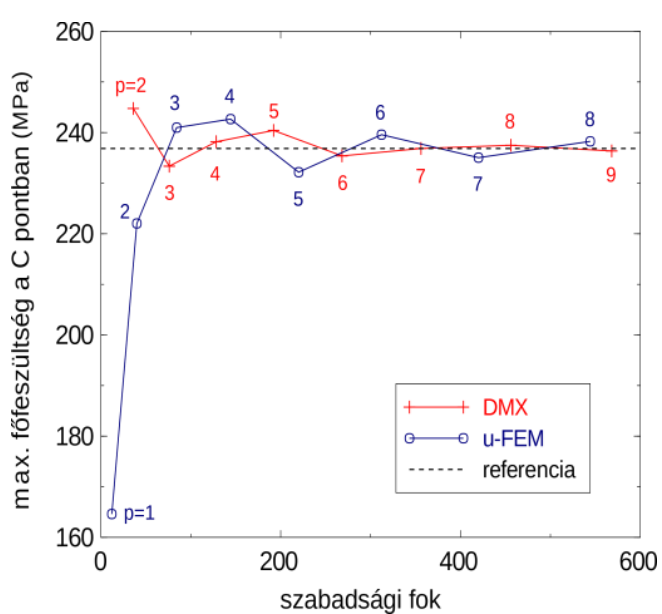

a)

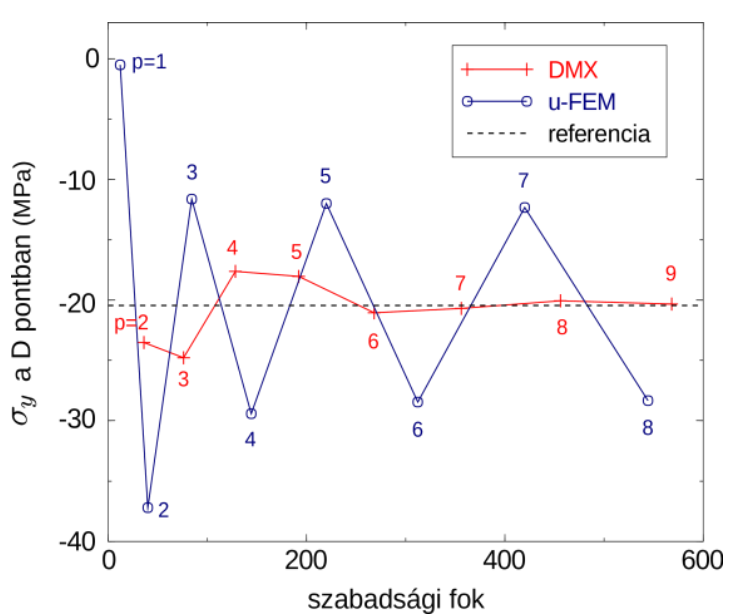

b)

3. ábra. a) Maximális föfeszültség konvergenciája a C pontban; b) $\sigma_{y}$ feszültség konvergenciája a D pontban

A 2.b) ábra azt szemlélteti, hogy a végeselemes megoldások milyen pontosan adják vissza a $\tau_{y x}$ nyírófeszültségre elöírt peremfeltételt a $G$ pontban. Látható, hogy a DMX elem $p>3$ esetén a pontos, $\tau_{y x}=$ 93,75 MPa értéket adja vissza, az u-FEM csak magasabb $p$ értékek esetében közelíti azt. A 3.a) ábra a $C$ pontbeli maximális föfeszültség konvergenciáját szemlélteti. A referencia megoldás értéke $\sigma_{1}^{\text {ref }}(C)=$ 236,9 MPa. A szakirodalomban ismert legjobb megoldás - konstans eloszlású terhelésnél $-\sigma_{1}(D)=$ 236,0 MPa. Látható, hogy a konvergencia görbék magasabb $p$ esetén hasonlóak, alacsony $p$ esetén viszont a DMX elem jobb megoldást ad, mint az u-FEM. A 3.b) ábra a $D$ pontbeli $\sigma_{y}$ normálfeszültség konvergenciáját mutatja. A referencia megoldás értéke $\sigma_{y}^{\text {ref }}(D)=20,36 \mathrm{MPa}$. A szakirodalomban ismert legjobb megoldás - konstans eloszlású terhelésnél $-\sigma_{y}(D)=20,10 \mathrm{MPa}$. Megállapítható, hogy a DMX elem konvergenciája éppen olyan jó, mint a főfeszültségek esetében, az u-FEM szerinti megoldás viszont nem mutat konvergenciát, $p$ növekedésével az elmozdulásmodellel számolt feszültségek a referencia megoldás körül - meglehetősen nagy amplitúdóval - oszcillálnak.

\section{5. Összegzés}

A feszültségi változók közvetlen approximációján alapuló végeselem-modelleket elsősorban olyan szilárdságtani problémáknál célszerü alkalmazni, amikor a hagyományos, elmozdulásmezőn alapuló végeselemeknél numerikus konvergencia problémák jelentkeznek. Közös ismertetőjele az ilyen feladattípusoknak, hogy a numerikus megoldás konvergenciája valamilyen jellemző paraméter értékétől függ, amelynek - fizikai jelentőséggel bíró - határértékénél a megoldás konvergenciája nem biztosítható. A legismertebb problémák közé tartoznak az összenyomhatatlan anyagok, valamint a vékony falú szerkezetek (lemezek és héjak) peremérték-feladatai. A sík-rugalmasságtani feladatokra és lemezekre $[15,16]$ ban kifejlesztett, elsőrendủ feszültségfüggvényeken és forgásokon alapuló végeselem-modell viselkedését ez a cikk egy olyan egyszerü - a szakirodalomban gyakran vizsgált - hajlítás-domináns tesztfeladat megoldásán keresztül mutatja be, amelyben semmilyen kritikus paraméter nem jelenik meg. A pverziós megoldásokat az elmozdulásmezőn alapuló, ugyancsak $p$-verziós - tehát kiváló approximációs tulajdonságokkal rendelkező - végeselem-modellekkel vetettük össze néhány jellemző pontbeli feszültség konvergenciáján keresztül. Megállapítható, hogy a vizsgált feladat esetében mindkét elem-modell 
kiváló eredményeket produkál, azonban a dual-mixed elem a feszültségi értékek gyorsabb konvergenciáját eredményezi, amely legszembetűnőbben a feszültségi peremfeltétel teljesülésénél jelentkezik.

\section{Köszönetnyilvánítás}

A cikkben ismertetett kutató munka az EFOP-3.6.1-16-2016-00011 jelü „Fiatalodó és Megújuló Egyetem - Innovatív Tudásváros - a Miskolci Egyetem intelligens szakosodást szolgáló intézményi fejlesztése" projekt részeként - a Széchenyi 2020 keretében - az Európai Unió támogatásával, az Európai Szociális Alap társfinanszírozásával valósult meg.

\section{Irodalom}

[1] Szabó, B., Babuška, I.: Finite Element Analysis, John Wiley \& Sons, Inc., 1991.

[2] Boffi, D., Brezzi, F., Fortin, M.: Mixed and Hybrid Finite Element Methods and Applications, Springer-Verlag, New York, 2013. https://doi.org/10.1007/978-3-642-36519-5

[3] Roberts, J. E., Thomas J.-M.: Mixed and hybrid methods. In Handbook of Numerical Analysis, Vol. II. (P. G. Ciarlet and J. L. Lions, eds.), North-Holland, Amsterdam, pp. 523-639, 1991. https://doi.org/10.1016/S1570-8659(05)80041-9

[4] Gallagher, R. H., Dhalla, A. K.: Direct flexibility finite element elastoplastic analysis, Proceedings of the First International Conference on Structural Mechanics in Reactor Technology, Part M, 6/9, pp. 444-462, Berlin, 1971.

[5] Fraeijs de Veubeke, B. M., Millard, A.: Discretization of stress fields in the finite element method, Journal of the Franklin Institute, 302 (1976) pp. 389-412. https://doi.org/10.1016/0016-0032(76)90032-6

[6] Gallagher, R. H.: Finite element structural analysis and complementary energy, Finite Element in Analysis and Design, 13 (1993) pp. 115-126. https://doi.org/10.1016/0168-874X(93)90051-Q

[7] Fraeijs de Veubeke, B.M.: A new variational principle for finite elastic displacements, International Journal for Engineering Sciences, 10 (1972) pp. 745-763. https://doi.org/10.1016/0020-7225(72)90079-1

[8] Fraeijs de Veubeke, B. M.: Diffusive equilibrium models. Lecture notes for the International Research Seminar on 'The theory and application of finite element methods', University of Calgary, Alberta, Canada, 1973. In: B. M. Fraeijs de Veubeke memorial volume of selected papers, (Geradin, M. ed.), Sijthoff \& Noordhoff, pp. 569-628, 1980. https://doi.org/10.1007/978-94-009-9147-7_14

[9] Fraeijs de Veubeke, B. M.: Stress function approach, Proc. World Cong. on Finite Element Methods in Structural Mechanics, J.1-J.51, Bournemouth, U.K., 1975.

[10] Atluri, S. N., Murakawa, H.: On hybrid finite element models in nonlinear solid mechanics, In Finite Elements in Nonlinear Mechanics (Edited by Bergan, P.G. et al.), Vol. 1. pp. 3-41. Tapir Press, Trondheim, Norway, 1977.

[11] Murakawa, H., Atluri, S. N.: Finite elasticity solutions using hybrid finite elements based on a complementary energy principle, Journal of Applied Mechanics, 45 (1978) pp. 539-547. https://doi.org/10.1115/1.3424358

[12] Murakawa, H., Atluri, S. N.: Finite elasticity solutions using hybrid finite elements based on a complementary energy principle, Part 2: Incompressible materials, Journal of Applied Mechanics, 46 (1979) pp. 71-77. https://doi.org/10.1115/1.3424531 
[13] Atluri, S. N.: On some new general and complementary energy theorems for the rate problems of finite strain, classical elasto-plasticity, Journal of Structural Mechanics, 8 (1980) pp. 61-92. https://doi.org/10.1080/03601218008907353

[14] Reed, K. W., Atluri, S. N.: Hybrid stress finite elements for large deformations of inelastic solids, Computers \& Structures, 19 (1984) pp. 175-182. https://doi.org/10.1016/0045-7949(84)90216-5

[15] Bertóti, E.: Dual-mixed hp finite element methods using first-order stress functions and rotations, Computational Mechanics, 26 (2000) pp. 39-51. https://doi.org/10.1007/s004660000148

[16] Bertóti, E.: Dual-mixed $p$ and hp finite element methods for elastic membrane problems, International Journal for Numerical Methods in Engineering, 53 (2002) pp. 3-29. https://doi.org/10.1002/nme.389

[17] Farhloul, M., Fortin, M.: Dual hybrid methods for the elasticity and the Stokes problems: a unified approach, Numerische Mathematik, 76 (1997) pp. 419-440. https://doi.org/10.1007/s002110050270

[18] Suri, M., Stenberg, R.: Mixed hp finite element methods for problems in elasticity and Stokes flow, Numerische Mathematik, 72 (1996) pp. 367-389. https://doi.org/10.1007/s002110050174

[19] Cook, R. D.: Improved two dimensional finite elements, ASCE Journal of Structural Engineering, ST6 (1974) pp. 1851-1863.

[20] Cazzani, A., Atluri, S. N.: Four-noded mixed finite elements, using unsymmetric stresses, for linear analysis of membranes, Computational Mechanics, 11 (1993) pp. 229-251. https://doi.org/10.1007/BF00371864

[21] Schröder, J., Klaas, O., Stein, E., Miehe, C.: A physically nonlinear dual mixed finite element formulation, Computer Methods in Applied Mechanics and Engineering, 144 (1997) pp. 77-92. https://doi.org/10.1016/S0045-7825(96)01169-3

[22] Ko, Y., Lee, P.-S., Bathe, K.-J.: The MITC4+ shell element and its performance, Computers \& Structures, 169 (2016) pp. 57-68. https://doi.org/10.1016/j.compstruc.2016.03.002

[23] Fortas, L., Belounar, L., Merzouki, T.: Formulation of a new finite element based on assumed strains for membrane structures, International Journal of Advanced Structural Engineering, 11 (2019) pp. 9-18. https://doi.org/10.1007/s40091-019-00251-9 